\title{
Latihan Kegel dan Nyeri Saat Berhubungan Seksual pada Perempuan Pasca Terapi Kanker
}

\author{
Dewi Puspasari, Mira Trisyani, Restuning Widiasih \\ Fakultas Keperawatan Universitas Padjadjaran \\ E-mail:dewi_246@yahoo.com
}

\begin{abstract}
Abstrak
Efek samping radioterapi adalah pemendekan dan pengeringan vagina yang menyebabkan nyeri saat melakukan hubungan seksual (dispareunia). Hal ini mengakibatkan gangguan fungsi seksual yaitu keinginan, gairah, orgasme, dan kepuasan. Penelitian ini bertujuan untuk melihat efektivitas latihan kegel dalam mengatasi keluhan nyeri saat berhubungan seksual pada perempuan pasca terapi kanker serviks. Penelitian ini menggunakan desain penelitian kuasi eksperimen dengan jumlah responsden 26 orang kelompok intervensi dan 26 orang kelompok kontrol pada perempuan setelah radioterapi. Tingkat nyeri dalam penelitian ini diukur dengan Female Sexual Function Index (FSFI). Pengaruh latihan kegel terhadap nyeri diuji dengan t-tes. Hasil penelitian menunjukkan adanya perbedaan yang bermakna pada kedua kelompok dengan nilai $p=0.002$. Latihan kegel terbukti menurunkan nyeri saat berhubungan seksual (dispareunia) sebanyak 3,897 kali $(\mathrm{OR}=3,897)$. Berdasarkan hasil penelitian ini, perawat diharapkan dapat memberikan intervensi latihan kegel untuk menurunkan nyeri pasca terapi kanker serviks.
\end{abstract}

Kata kunci: Dispareunia, latihan kegel, pasca terapi kanker serviks

\section{Kegel Exercise and Pain During Sexual Intercouse Related to Women Post- Cancer Treatment}

\begin{abstract}
Radiotherapy for cervical cancer has side effects which cause the vagina become smaller and drier so that it could reduce the flexibility and lubrication of the vagina. These side effects could change the sexual functions, which is pain during sexual intercourse. This study proves the effectiveness of Kegel exercises to overcome pain during sexual intercourse (dyspareunia) for the women after a cervical cancer therapy. Method The Quasi-experimental was conducted to 26 intervention group and 26 control group. The sampling technique used consecutive sampling method. FSFI (Female Sexual Function Index) were obtained in order to measure dyspareunia. A t-test was used to examine differences between two groups. Result findings The Kegel exercises gave a significant changing of dyspareunia level with $\mathrm{p}$ value $=0,002$. There was significance difference of dyspareunia level between intervention and control groups. Kegel exercises provided opportunies to decrease dyspareunia as much as 3,897 times $(\mathrm{OR}=3,897)$. Conclusion The Kegel exercises are proved to reduce effectively to solve dyspareunia for women after a cervical cancer therapy. Nursing role are to promote, prevent and rehabilitate (health education, Kegel exercises sosialization, and health care training) the complaint of women after cervical cancer therapy as an effort to improve health status of women with cervical cancer.
\end{abstract}

Key words: After cervical cancer therapy, dyspareunia, kegel exercises 
Dewi Puspasari: Latihan Kegel dan Nyeri saat Berhubungan Seksual

\section{Pendahuluan}

Prevalensi penderita kanker serviks di dunia semakin bertambah setiap tahunnya sebanyak 6,25 juta orang (World Health Organization [WHO], 2007). Dalam 10 tahun mendatang diperkirakan 9 juta orang akan meninggal setiap tahunnya karena kanker. Dua pertiga dari penderita kanker di dunia berada di negara-negara yang sedang berkembang. Di Indonesia diperkirakan setiap tahunnya terdapat 100 penderita kanker baru dari setiap 100.000 penduduk. Peringkat tertinggi kanker yang dialami oleh penderita di Indonesia adalah kanker serviks sebesar 16,5\% (Departemen Kesehatan Republik Indonesia [Depkes RI], 2007).

Pengobatan kanker serviks dapat dilakukan dengan cara pembedahan, terapi radiasi, kemoterapi, dan gabungan antara ketiga terapi tersebut (Spencer, 2007). Setiap terapi kanker serviks memberikan keuntungan maupun kerugian dan efek samping terhadap sistem tubuh. Terapi radiasi menyebabkan pemendekan dan pengeringan vagina dengan disertai hilangnya fleksibilitas dan cairan lubrikan daerah vagina yang dapat menyebabkan dispareunia, sehingga terjadi perubahan pada fungsi seksual yaitu keinginan, gairah, orgasme, dan kepuasan (Jordan \& Singer, 2006). Roughan dan Knust (2001) menyatakan bahwa perempuan dengan terapi radiasi kanker serviks stadium I, II, dan III menimbulkan masalah pada fungsi seksualnya, seperti penurunan kenikmatan dalam hubungan seksual, kesulitan untuk mencapai orgasme, libido, frekuensi hubungan seksual, dan kesempatan untuk berhubungan seksual.

Hasil studi longitudinal kuantitatif yang mengkaji fungsi seksual dan perubahan vagina pada wanita dengan kanker serviks $(n=118)$ menyebutkan bahwa terjadi pengalaman disfungsi seksual pada wanita dengan kanker serviks sampai dengan 2 tahun setelah dilakukan perawatan terapi radiasi, Adapun $60,9 \%$ terjadi penurunan keinginan/hasrat seksual, 62,5\% penurunan cairan lubrikasi vagina, $55 \%$ terjadi dispareunia berat dan $45 \%$ dari wanita setelah terapi radiasi tidak pernah atau jarang sekali mau melakukan hubungan seksual dengan pasangannya (Jensen, dkk., 2003). Berkurangnya keinginan hubungan seksual biasa terjadi pada wanita dengan terapi kanker $(61 \%, \mathrm{n}=66)$ dibanding dengan wanita yang tidak melakukan terapi, kekeringan vagina pada wanita setelah terapi kanker $(80 \%, n=93)$, nyeri atau ketidaknyamanan saat hubungan seksual/dispareunia (62\%, $\mathrm{n}=72$ ), dan ketidakmampuan atau kesulitan mencapai orgasme $(75 \%, n=87)$ (Taylor \& Basen-Engquist, 2004).

Salah satu terapi nonfarmakologi yang bertujuan untuk meningkatkan kenyamanan dalam upaya mengatasi dispareunia dan kesulitan orgasme pada perempuan pasca terapi kanker serviks adalah dengan latihan kegel. Latihan kegel adalah latihan pada otot-otot pelvis dengan cara mengerutkan (kontraksi) dan mengendurkan (relaksasi) yang dilakukan secara kontinu atau berulangulang (Roger, 2008). Tujuan latihan kegel ini untuk menguatkan otot-otot dasar panggul yang dapat dilakukan sampai 24 minggu (6 bulan) untuk mendapatkan hasil yang optimal (Fonda, 2000; Anders, 2001; Wyman \& Fantl, 2001; Newman \& Wein, 2009).

Penelitian menunjukkan latihan kegel bermanfaat untuk mencegah terjadinya ejakulasi dini dan meningkatkan kepuasan seksual (La Pera \& Nicastro, 1996). Penelitian lain menunjukkan bahwa Pelvic Floor Muscle Exercises (PFME) atau latihan kegel sangat efektif meningkatkan kekuatan otot dasar panggul, dan kualitas hidup seseorang (Aslan, Komurcu, Beji \& Yalcin, 2008). Penelitian menunjukkan bahwa pendekatan yang dapat dilakukan untuk mengatasi dispareunia adalah melalui terapi fisik (latihan otot dasar panggul/latihan kegel, manajemen nyeri, dan terapi seks) dan psikoseksual (Cognitive Behaviour Therapy/CBT) (Haefner, dkk., 2005; Weijmar, dkk., 2005).

Latihan kegel merupakan metode alternatif untuk mengatasi dispareunia dan kesulitan orgasme. Penerapan latihan kegel ini masih sangat terbatas dalam mengatasi masalah nyeri daerah vagina dan gangguan fungsi seksual sebagai akibat efek samping pengobatan kanker. Berdasarkan pada penelitian sebelumnya menurut Haefner, dkk. (2005) dan Weijmar, dkk. (2005) bahwa latihan kegel ini mampu mengatasi dispareunia yang dapat berakibat pada komplikasi yang lebih berat, seperti disfungsi seksual atau ketidakmampuan mencapai orgasme. Latihan kegel dapat membuat relaks 
Dewi Puspasari: Latihan Kegel dan Nyeri saat Berhubungan Seksual

otot vagina yang membantu vagina menjadi basah sampai dengan keduanya merasa bergairah, sehingga dapat mengurangi nyeri saat hubungan seksual. Latihan kegel dapat membantu mengatasi masalah dispareunia sehingga fase orgasme dapat tercapai.

Metode ini penting untuk dikembangkan dan dibuktikan efektifitasnya secara ilmiah, sehingga dapat dijadikan sebagai solusi alternatif dalam mengurangi keluhan dispareunia dan mengatasi masalah gangguan fungsi seksual (kesulitan orgasme) pada perempuan pasca terapi kanker serviks disamping terapi farmakologi. Berdasarkan latar belakang di atas, penelitian yang akan dilakukan bertujuan untuk mengeksplorasi efektivitas latihan kegel dalam mengatasi keluhan dispareunia pada perempuan pasca terapi kanker serviks (Wabe, Angamo, \& Hussein, 2011)

Tujuan penelitian ini adalah untuk mengetahui pengaruh latihan kegel dalam mengatasi keluhan dispareunia pada perempuan pasca terapi kanker serviks. Hasil penelitian dapat digunakan sebagai dasar dibuatnya dalam upaya promotif, preventif dan rehabilitatif terhadap keluhan yang akan dirasakan setelah terapi kanker serviks sebagai upaya untuk meningkatkan derajat kesehatan perempuan dengan kanker serviks dan sebagai upaya pemerintah dalam meningkatkan kualitas hidup ibu dengan kanker serviks, terutama kebutuhan akan rasa nyaman dalam memenuhi kebutuhan dasar manusia, yaitu kebutuhan biologis (kebutuhan seksual).

\section{Metode Penelitian}

Penelitian ini adalah merupakan penelitian kuantitatif dengan menggunakan desain kuasi eksperimen, dimana peneliti memberikan perlakuan atau intervensi pada kelompok subjek penelitian, kemudian efek perlakuan diukur dan dianalisis.

Pada tahapan prosedur administratif pengumpulan data, peneliti mengurus perijinan di tempat penelitian. Setelah mendapat ijin, kemudian dilakukan tahap prosedur teknis penelitian. Pada tahap pertama peneliti melakukan uji cobakuesionerkepada 20 orang perempuan pasca terapi radiasi di Rumah
Sakit Hasan Sadikin Bandung dan melakukan uji validitas dan reliabilitas instrumen. Kemudian peneliti menentukan satu orang perawat ruangan dengan pendidikan minimal D3 keperawatan untuk membantu peneliti dalam pemilihan responsden melalui catatan medik keperawatan klien.

Pada tahap berikutnya, peneliti melakukan pertemuan dengan perawat ruangan untuk menjelaskan tentang prosedur penelitian dan metode pemilihan kelompok responsden yang telah disesuaikan dengan kriteria inklusi. Kemudian peneliti menetapkan responsden dengan menggunakan formulir penapisan responsden. Formulir penapisan ini digunakan untuk menyeleksi klien yang dapat dijadikan sebagai responsden dalam penelitian ini. Peneliti mengisi formulir penapisan responsden sebanyak 12 item pertanyaan, bila item no 1, 2, 3, 4, 5, 6, 8, 11 klien menjawab "Ya" dan item no 7, 9, 10, 12 klien menjawab "Tidak", maka klien masuk menjadi responsden.

Penentuan jumlah responsden pada kelompok intervensi dilakukan pada bulan pertama sampai jumlah responsden sesuai dengan besar sampel yang telah ditentukan. Pengambilan responsden pada kelompok kontrol dilakukan pada bulan selanjutnya setelah kelompok intervensi terpenuhi.

Pada pertemuan hari pertama saat responsden kontrol ke Rumah Sakit Hasan Sadikin Bandung, peneliti menjelaskan tujuan penelitian kepada responsden. Setelah mendapatkan penjelasan, responsden diminta untuk mengisi lembar persetujuan mengikuti penelitian (informed consent). Kelompok intervensi dan kontrol mengisi formulir data demografi (karekteristik responsden) dan kuesioner pengetahuan tentang kanker serviks, terapi, dan efek sampingnya. Pada kelompok intervensi diberikan pelatihan tentang latihan kegel selama 1 hari di ruang pertemuan poliklinik onkologi Rumah Sakit Hasan Sadikin Bandung. Responsden diberitahukan untuk melakukan latihan kegel selama enam bulan, dimana latihan dilakukan selama lima hari dalam seminggu. Responsden diberikan modul tentang kanker serviks dan latihan kegel.

Peneliti menentukan pengawas latihan kegel selama di rumah dengan meminta kepada suami yang memahami kondisi responsden 
Dewi Puspasari: Latihan Kegel dan Nyeri saat Berhubungan Seksual

dan selalu mendampingi responsden saat berobat ke Rumah Sakit. Peneliti selanjutnya menjelaskan dan melakukan latihan tentang prosedur pengisian lembar self report kepada responsden pada kelompok intervensi beserta suaminya sebagai pengawas pelaksanaan latihan selama di rumah.

Pada bulan ke-3 (Agustus) peneliti melakukan kunjungan rumah responsden untuk mengevaluasi pengisian self report dan latihan kegel selama dirumah. Pada bulan ke-6 (November) ketika responsden di kelompok kontrol maupun intervensi melakukan kontrol ke poliklinik onkologi Rumah Sakit Hasan Sadikin Bandung dilakukan pengukuran dispareunia dengan menggunakan kuesioner FSFI

Kelompok kontrol mendapatkan pelatihan tentang latihan kegel setelah pengumpulan data selesai dan juga diberikan modul sebagai panduan. Kemudian peneliti melakukan rencana tindak lanjut (RTL) tentang kemajuan dan perkembangan klien serta rencana tindak lanjut yang harus dilakukan klien pada tahun I setelah dilakukan latihan.

Alat pengumpulan data terbagi menjadi tiga instrumen, yaitu kuesioner tentang karekteristik demografi responsden, FSFI dan self report, serta kuesioner pengetahuan. Instrumen penelitian terlebih dahulu dilakukan uji validitas dan reliabilitas pada 20 subjek penelitian di Rumah Sakit Hasan Sadikin Bandung. Hasiluji validitas instrumen FSFI yaitu variabel nyeri yang memiliki nilai Pearson Correlation $\mathrm{R}>\mathrm{r}(\mathrm{r}=0.686)$ dengan korelasi yang signifikan (nilai $p>0.05$ ). Hasil uji reliabilitas instrumen pada variabel nyeri dengan nilai Alpha Cronbach's 0.639>0.5. Instrumen dinyatakan reliabel atau dapat dipercaya. Self report digunakan sebagai laporan pelaksanaan latihan kegel yang dilaksanakan selama dirumah yang diisi oleh responsden pada kelompok intervensi. Pengisian laporan pelaksanaan latihan kegel dilakukan selama enam bulan.

Lokasi penelitian ini dilaksanakan di Poliklinik Onkologi Rumah Sakit Umum Pusta (RSUP) Hasan Sadikin Bandung, rumah sakit yang merupakan rujukan di Kota Bandung, dan yayasan kanker. Waktu pelaksanaan penelitian efektif selama enam bulan terhitung mulai Juni-November 2012. Sampel dalam penelitian ini adalah perempuan yang terdiagnosa kanker serviks baik lama atau baru yang telah melakukan terapi radiasi pada pengobatan kanker serviks di Poliklinik Onkologi RSUP Hasan Sadikin Bandung pada saat dilakukan penelitian dengan kriteria inklusi sebagai berikut: klien sudah menyelesaikan pengobatan terapi radiasi dan sudah melakukan hubungan seksual dalam satu bulan terakhir dengan suami; klien mengalami dispareunia superfisial pasca terapi kanker serviks; klien hanya melakukan terapi latihan kegel untuk mengatasi masalah seksual; klien tinggal bersama suami dan datang ke pelayanan kesehatan beserta suami; klien tidak mengalami dispareunia sebelum menderita kanker serviks

Teknik pengambilan sampel dalam penelitian ini menggunakan non probability sampling yaitu consecutive sampling. Penentuan besar sampel yang diambil adalah dengan menggunakan rumus uji hipotesis perbedaan two mean dependen/paired sample (Ariawan, 1998). Besar sampel dalam penelitian ini adalah 52 responsden yang terbagi menjadi 26 orang kelompok intervensi dan 26 orang kelompok kontrol, untuk mengantisipasi drop out pada sampel ditambahkan 10\% sehingga jumlah sampel keseluruhan adalah 58 responsden yang terbagi menjadi 29 orang kelompok intervensi dan 29 orang kelompok kontrol.

\section{Hasil Penelitian}

Responsden dalam penelitian ini adalah ibu dengan karekteristik usia mayoritas berusia $\geq 35$ tahun. Sebagian besar ibu dalam penelitian ini tidak bekerja, sedangkan tingkat pendidikan pada kelompok kontrol, setengahnya mendapatkan pendidikan tingkat dasar dan selebihnya mendapatkan pendidikan lanjut. Pendidikan pada kelompok intervensi sebagian besarnya menunjukkan ibu mendapatkan pendidikan dasar dan hanya sebagian kecil saja yang mendapatkan pendidikan lanjut. Sebagian besar ibu pada kedua kelompok berada pada tingkat pengetahuan yang cukup, sedangkan sebagian kecil ibu dengan tingkat pengetahuan yang kurang (Tabel 1).

Karekteristik responsden tidak memiliki pengaruh terhadap penurunan dispareunia 
Dewi Puspasari: Latihan Kegel dan Nyeri saat Berhubungan Seksual

Tabel 1 Karekteristik Perempuan Pasca Terapi Kanker Serviks pada Kelompok Intervensi dan Kelompok Kontrol di Rumah Sakit Hasan Sadikin Bandung, November 2012 (n=52)

\begin{tabular}{lcccc}
\hline \multirow{2}{*}{ Karekteristik } & \multicolumn{2}{c}{ Kel. Kontrol } & \multicolumn{2}{c}{ Kel. Intervensi } \\
& $\begin{array}{c}\text { Frekuensi } \\
\mathbf{n = 2 6}\end{array}$ & $\begin{array}{c}\text { Persentase } \\
\mathbf{( \% )}\end{array}$ & $\begin{array}{c}\text { Frekuensi } \\
\mathbf{n = 2 6}\end{array}$ & $\begin{array}{c}\text { Persentase } \\
\mathbf{( \% )}\end{array}$ \\
\hline Usia & 4 & 15,4 & 0 & 0 \\
$\begin{array}{l}\text { 19-35 tahun } \\
\text { >35 tahun }\end{array}$ & 22 & 84,6 & 26 & 100 \\
$\begin{array}{l}\text { Pekerjaan } \\
\text { Bekerja }\end{array}$ & 8 & 30,8 & 2 & 7,7 \\
Tidak Bekerja & 18 & 69,2 & 24 & 92,3 \\
$\begin{array}{l}\text { Pendidikan } \\
\text { Pendidikan dasar (SD \& SLTP) }\end{array}$ & 13 & 50 & 23 & 88,5 \\
$\begin{array}{l}\text { Pendidikan lanjut (SLTA \& PT) } \\
\text { Pengetahuan }\end{array}$ & 13 & 50 & 3 & 11,5 \\
Cukup & & & & \\
Kurang & 20 & 76,9 & 17 & 65,4 \\
& 6 & 23,1 & 9 & 34,6 \\
\hline
\end{tabular}

(nilai $p>0.05$ ), sedangkan latihan kegel berpengaruh terhadap penurunan dispareunia (nilai $p<0.05$ ). Kekuatan hubungan yang paling berpengaruh terhadap kondisi dispareunia adalah latihan kegel $(\mathrm{OR}=3.897)$, pengetahuan $(\mathrm{OR}=0.828)$, pendidikan $(\mathrm{OR}=0.000)$, dan pekerjaan $(\mathrm{OR}=0.000)$. Peningkatan intensitas latihan kegel akan memberikan peluang sebanyak 3,897 kali untuk menurunkan dispareunia. Latihan kegel dengan nilai $\mathrm{B}=19,189$ memiliki kekuatan hubungan yang positif, semakin meningkat latihan kegel akan menyebabkan penurunan nyeri (Tabel 2).

Hasil penelitian menunjukkan semua variabel dalam karekteristik responsden memiliki nilai $p>0.05$ yang berarti tidak terdapat hubungan yang bermakna antara karekteristik responsden dengan dispareunia pada kedua kelompok. Terdapat faktor-faktor lain yang berhubungan dengan dispareunia diluar variabel dalam karekteristik responsden. Hasil analisis bivariat chi square antara kelompok kontrol dan kelompok intervensi menghasilkan usia, pekerjaan, dan pengetahuan dengan nilai $p>0.05$ yang berarti tidak terdapat hubungan karekteristik responsden terhadap dispareunia yang signifikan pada kelompok intervensi dan kontrol. Pendidikan pada kelompok intervensi dan kelompok kontrol memberikan hubungan yang signifikan terhadap dispareunia dengan nilai $p<0.05$ (Tabel 3).

Tabel 2 Pengaruh Variabel Independen terhadap Dispareunia pada Kelompok Intervensi dan Kelompok Kontrol di Rumah Sakit Hasan SadikinBandung, November $2012(\mathrm{n}=52)$

\begin{tabular}{lccccc}
\hline \multirow{2}{*}{ Variabel } & \multirow{2}{*}{ B } & \multirow{2}{*}{ P value } & \multirow{2}{*}{ OR } & \multicolumn{2}{c}{ 95 \% CI } \\
\cline { 5 - 6 } & & & & Lower & Upper \\
\hline Latihan kegel & 19,189 & 0.002 & 3,897 & 0.149 & 26,723 \\
Pengetahuan & 0.692 & 0.695 & 0.828 & 0.08 & 30,867 \\
Pendidikan & 9,534 & 0.999 & 0.000 & 0.022 & 5.027 \\
Pekerjaan & 0.052 & 0.998 & 0.000 & 0.023 & 5.814 \\
\hline
\end{tabular}


Dewi Puspasari: Latihan Kegel dan Nyeri saat Berhubungan Seksual

Tabel 3 Hubungan Karekteristik Responsden terhadap Dispareunia pada Kelompok Intervensi dan Kelompok Kontrol di Rumah Sakit Hasan Sadikin Bandung, November 2012 $(\mathbf{n}=52)$

\begin{tabular}{|c|c|c|c|c|c|c|c|c|c|}
\hline \multirow{3}{*}{ Variabel } & \multicolumn{6}{|c|}{ Dispareunia } & \multirow{2}{*}{\multicolumn{2}{|c|}{ Total }} & \multirow{3}{*}{$P$ Value } \\
\hline & \multicolumn{2}{|c|}{ Ringan } & \multicolumn{2}{|c|}{ Sedang } & \multicolumn{2}{|c|}{ Berat } & & & \\
\hline & $\mathbf{N}$ & $\%$ & $\mathbf{N}$ & $\%$ & $\mathbf{N}$ & $\%$ & $\mathbf{n}$ & $\%$ & \\
\hline \multicolumn{10}{|l|}{ Usia } \\
\hline 19-35 tahun & 0 & 0 & 3 & 5,8 & 1 & 1,9 & 4 & 7,7 & 0.075 \\
\hline \multirow[t]{2}{*}{$>35$ tahun } & 32 & 61,5 & 13 & 24,9 & 3 & 5,9 & 48 & 92,3 & \\
\hline & 32 & 61,5 & 16 & 30,7 & 4 & 7,8 & 52 & 100 & \\
\hline \multicolumn{10}{|l|}{ Pekerjaan } \\
\hline Bekerja & 29 & 55,8 & 10 & 19,2 & 3 & 5,9 & 42 & 80,8 & 0.170 \\
\hline \multirow[t]{2}{*}{ Tidak Bekerja } & 3 & 5,7 & 6 & 11,6 & 1 & 1,9 & 10 & 19,2 & \\
\hline & 32 & 61,5 & 16 & 30,8 & 4 & 7,8 & 52 & 100 & \\
\hline \multicolumn{10}{|l|}{ Pendidikan } \\
\hline $\begin{array}{l}\text { Pendidikan dasar (SD \& } \\
\text { SLTP) }\end{array}$ & 25 & 48,1 & 9 & 17,3 & 2 & 3,9 & 36 & 69,3 & 0.458 \\
\hline \multirow{2}{*}{$\begin{array}{l}\text { Pendidikan lanjut (SLTA } \\
\& \text { PT) }\end{array}$} & 7 & 13,4 & 7 & 11,6 & 2 & 3,9 & 16 & 30,7 & \\
\hline & 32 & 61,5 & 15 & 28,9 & 4 & 7,8 & 52 & 100 & \\
\hline \multicolumn{10}{|l|}{ Pengetahuan } \\
\hline Baik & 0 & 0 & 0 & 0 & 0 & 0 & 0 & 0 & 1.000 \\
\hline Cukup & 22 & 42,3 & 12 & 25 & 3 & 5,9 & 37 & 71,1 & \\
\hline \multirow[t]{2}{*}{ Kurang } & 10 & 19,2 & 4 & 7,7 & 1 & 1,9 & 15 & 28,9 & \\
\hline & 32 & 61,5 & 17 & 32,7 & 4 & 7,8 & 52 & 100 & \\
\hline
\end{tabular}

\section{Pembahasan}

Hasil penelitian menunjukkan bahwa latihan kegel berpengaruh secara bermakna pada keluhan dispareunia. Tingkat nyeri pada kelompok intervensi yang diberikan latihan kegel lebih rendah dibanding dengan kelompok kontrol. Tingkat nyeri yang dihasilkan pada kelompok intervensi yang diberikan latihan kegel hampir seluruhnya berada pada tingkat nyeri ringan. Sedangkan tingkat nyeri pada kelompok kontrol yang tidak diberikan latihan kegel lebih dari setengahnya berada pada tingkat nyeri sedang, dan sebagian kecil berada pada tingkat nyeri ringan dan berat.

Nyeri saat berhubungan seksual ditimbulkan akibat efek samping terapi radiasi sebagai salah satu penangaan kanker serviks. Terapi radiasi menyebabkan pemendekan dan pengeringan vagina dengan disertai hilangnya fleksibilitas dan cairan lubrikan daerah vagina (Jordan \& Singer, 2006). Hal ini menyebabkan perempuan mengalami dispareunia. Masalah yang sering timbul pada wanita dengan terapi kanker serviks adalah nyeri atau ketidaknyamanan saat hubungan seksual/ dispareunia $(62 \%, \mathrm{n}=72)$ (Taylor \& BasenEngquist, 2004). Berdasarkan data yang diperoleh dari responsden penelitian, nyeri saat berhubungan seksual pada perempuan yang telah dilakukan terapi radiasi dirasakan setelah selesai terapi radiasi. Kondisi seperti ini dapat membuat ibu enggan berhubungan seksual sehingga menyebabkan disfungsi seksual sampai dengan kurun waktu dua tahun (Jensen, dkk., 2003). Graziottin (2005) menyatakan dispareunia merupakan nyeri yang timbul dalam hubungan seksual yang dapat menimbulkan gangguan atau disfungsi seksual.

Pada penelitian ini nyeri yang diukur adalah nyeri saat melakukan hubungan seksual yang dirasakan hanya sesaat dan tidak mengganggu aktivitas ibu, yang disebut 
Dewi Puspasari: Latihan Kegel dan Nyeri saat Berhubungan Seksual

sebagai dispareunia superfisial. Menurut Moore, Lam, dan Kay (2010) dispareunia dibagi menjadi dua berdasarkan faktor risiko terjadinya dispareunia yaitu superficial dyspareunia dan deep dyspareunia. Kahan, Miller, dan Smith (2009) mendefinisikan superficial dyspareunia adalah nyeri atau disfungsi yang dirasakan pada saat awal penetrasi dalam hubungan seksual, sedangkan deep dyspareunia adalah nyeri atau disfungsi yang dirasakan lebih dalam di area pelvis selama atau sesudah hubungan seksual. Berbagai faktor yang menyebabkan terjadinya dispareunia pada perempuan dengan kanker serviks setelah menjalani terapi pengobatan.

Hasil wawancara dengan responsden didapatkan, salah satu penyebab dispareunia adalah karena terjadinya pemendekkan dan kekakuan pada vagina serta vagina yang menjadi kering dan sempit membuat nyeri pada saat hubungan seksual. Greimel, Winter, dan Kapp (2009) mengungkapkan tentang fungsi seksual setelah terapi kanker serviks mengungkapkan bahwa keluhan vagina menjadi sempit secara signifikan lebih tinggi ditemukan pada perempuan yang menjalani terapi radiasi dibanding kelompok lain dengan pembedahan dan kemoterapi.

Menurut Daneilsson (2001) superficial dyspareunia dihubungkan dengan faktor risiko seperti adanya atrofi otot, vaginismus, vulval vestibulitis, kurang pengalaman dalam hubungan seksual, provoked vestibulodynia (PVD) dan atrofi vulvovaginal. Superficial dyspareunia dengan karekteristik nyeri yang bersifat di permukaan dan bersifat sementara, sedangkan deep dyspareunia dalam dengan karekteristik nyeri yang lebih dalam dan bersifat kontinu. Deep dyspareunia dihubungkan dengan faktor risiko seperti adanya PID, endometriosis, kista ovarium, cystitis, adesi pada pelvis, sindrom sumbatan pada pelvis, dan uterus retroversi (Moore, dkk., 2010).

Penanganan yang dapat dilakukan untuk mengatasi masalah dispareunia, Penanganan yang dilakukan tergantung dari penyebab dispareunia itu sendiri. Pada perempuan pasca terapi radiasi dispareunia disebabkan oleh adanya perubahan struktur otot-otot vagina, maka penanganannya adalah berupa latihan fisik yang mengembalikan kembali fungsi otot-otot vagina menjadi elastis. Menurut Graziottin (2005) penanganan dispareunia tergantung pada penyebabnya, yaitu faktor otot dapat ditangani dengan cara meningkatkan regulasi sistem muskuler dengan cara masase, terapi fisik pada otot levator ani dan otot pubococcygeus, latihan otot dasar panggul melalui kontraksi dan relaksasi (latihan kegel) untuk mengontrol kemampuan kerja otot. Latihan kegel dengan cara mengerutkan (kontraksi) dan mengendurkan (relaksasi) otot dasar panggul membantu otot dasar panggul menjadi elastis dan mengurangi kekakuan, yang menyebabkan nyeri saat hubungan seksual.

Latihan kegel terbukti dapat mengatasi masalah nyeri saat hubungan seksual pada perempuan pascaterapi kanker serviks. Manfaat latihan kegel yang lainnya adalah dapat meningkatkan kepuasan seksual (La Pera \& Nicastro, 1996), membuat relaks otot vagina dengan membantu vagina menjadi basah, sehingga dapat mengurangi nyeri saat berhubungan seksual. Latihan kegel juga merupakan terapi bagi pasangan, dimana saat hubungan seksual, perempuan yang mempraktekkan latihan kegel dengan cara mengerutkan dan mengendurkan otot vaginanya, dapat dirasakan pergerakannya oleh suami dan membantu pasangan masuk tahap bergairah (Haefner, dkk., 2005 \& Weijmar, dkk., 2005). Latihan kegel sebagai salah satu alternatif tindakan yang dapat dilakukan untuk mengatasi masalah dispareunia, sehingga kecemasan, ketakutan, dan keengganan untuk melakukan hubungan seksual dapat diatasi. Faktor kecemasan, ketakutan, dan keengganan melakukan hubungan seksual dapat menyebabkan masalah disfungsi seksual dan terjadinya perubahan struktur anatomi dari vagina yang semakin memendek, mengering, dan tidak fleksibel. Hal ini dapat menyebabkan tidak terpenuhinya kebutuhan biologis dan menurunnya kualitas hidup perempuan dengan kanker serviks yang dilakukan terapi radiasi.

Latihan kegel menurunkan kemungkinan gangguan fungsi seksual. Latihan kegel dengan melakukan kontraksi (mengerutkan) dan relaksasi (mengendurkan) otot dasar panggul dapat membantu elastisitas vagina. 
Dewi Puspasari: Latihan Kegel dan Nyeri saat Berhubungan Seksual

Elastisitas vagina dapat membuat vagina menjadi basah dengan cairan lubrikan yang dapat mengurangi keluhan dispareunia pada perempuan pasca terapi kanker serviks. Struktur vagina yang elastis menjadi salah satu solusi yang dapat dilakukan dalam mengatasi masalah dispareunia yang dapat memberikan dampak lebih lanjut, seperti disfungsi seksual (gangguan minat, gairah, orgasme, dan kepuasan seksual). Faktor lain seperti faktor psikologis. Faktor psikoseksual sebagai salah satu penyebab dispareunia disebabkan karena adanya gangguan keinginan/gairah seksual, kekerasan, depresi, atau konflik dengan pasangan (Graziottin, 2003).

Perawat sebagai salah satu tenaga kesehatan yang terdekat dengan pasien, memiliki peran yang sangat penting terutama dalam pemberian asuhan keperawatan pada ibu yang mengalami masalah dispareunia. Perawat dapat memberikan edukasi berupa latihan kegel pada ibu yang mengalami dispareunia. Latihan kegel dilakukan secara berkesinambungan dengan melibatkan peran ibu dan keluarga.

\section{Simpulan}

Berdasarkan hasil penelitian diatas dapat disimpulkan bahwa latihan kegel berpengaruh secara bermakna terhadap penurunan dispareunia. Hal ini ditunjukkan dari adanya perbedaan tingkat nyeri pada kelompok intervensi yang menunjukkan tingkat nyeri ringan sedangkan pada kelompok kontrol menunjukkan tingkat nyeri sedang, bahkan sebagian kecil menunjukkan tingkat nyeri berat. Hasil penelitian ini menunjukkan bahwa pemberian informasi tentang latihan kegel dalam upaya mengatasi masalah keluhan dispareunia dapat menjadi prosedur tetap Rumah Sakit. Perawat dapat berperan dalam memberikan edukasi mengenai latihan kegel pada ibu dengan dispareunia.

\section{Daftar Pustaka}

Anders, K. (2001). Bladder retraining. In Stanton S.L., Monga A.K (eds.), Clinical urogynecology. London: Churchill Livingstone.
Ariawan, I. (1998). Besar dan metode sampel pada pendidikan kesehatan. Jakarta: Jurusan Biostatistika \& Kependudukan FKM UI.

Aslan, E., Komurcu, N., Beji, N.K., \& Yalcin, O. (2008). Bladder training and kegel exercises for women with urinary complaints living in a rest home. Gerontology, 54, 224 231.

Danielsson, I. (2001). Dyspareunia in women with special reference to vulvar vestibulitis. Unpublished doctoral disertation, Umea University, Sweden.

Departemen Kesehatan Republik Indonesia (Depkes RI). (2007). Survey kesehatan rumah tangga. Jakarta: Depkes RI.

Fonda, D. (2000). Management of the incontinent older people. International Continence Surv, 2, 2-9.

Graziottin, A. (2005). Female sexual dysfunction. In Bo, K., Berghmans, B., van Kampen, M., Morkved, S (eds.), Evidence based physiotherapy for the pelvic floor: Bringing research and clinical practice. Oxford: Elsevier.

Greimel, E. R., Winter, R., Kapp, K. S., \& Hass, J. (2009). Quality of life and sexual fuctioning after cervical cancer treatment: A long-term follow up study. Psychooncology, 18(5), 476-82. doi: 10. 1002/pon. 1426.

Haefner, H.K., Collins, M.E., Davis, G.D., Edwards, L., Foster, D. C., Hartmann, A. D. H., ... Wilkinson, S. J. (2005). The vulvodynia guideline. Journal Low Genit Tract Disease, 9(1), 40-51.

Jensen, P., Groenvold, M., Klee, M., Thranov, I., Petersen, M., \& Machin, D. (2003). A longitudinal study of sexual function and vaginal changes after radiotherapy for cervical cancer. International Journal of Radiation Oncology Biology Physics, 56(4). 937-949.

Jordan, J.A., \& Singer, A. (2006). The cervix 
Dewi Puspasari: Latihan Kegel dan Nyeri saat Berhubungan Seksual

(2nd ed.). UK: Blackwell Publishing Ltd. Kahan, S., Miller, R., \& Smith, E. G. (2009). In a page sign's \& symptoms (2nd ed.). Philadelphia: Lippincott William's \& Wilkins.

La Pera, G., \& Nicastro, A. (1996). A new treatment for premature ejaculation: A rehabilitation of the pelvic floor. Journal Sex Marital Ther, 22(1), 22-6.

Moore, M., Lam, S.J., \& Kay, A. R. (2010). Rapid obstetrics and gynaecology (2nd ed.). UK: John Wiley \& Sons.

Newman, D.K., \& Wein, A.J. (2009). Managing and treating urinary incontinence (2nd ed.). Baltimore: Health Professions Press.

Rogers, R. G. (2008). Clinical practice. Urinary stres incontinence in women. $N$

Engl J Med, 358(10), 1029-36. doi: 10. 1056/ NEJMcp0707023.

Roughan, P.A., \& Knust L. (2001). Do pelvic floor exercises really improve orgasmic potential?. J Sex Marital Ther, 7, 223-229.

Spencer, J.V. (2007). Deadly diseases and epidemics: Cervical cancer. New York: Chelsea House.
Taylor, C.C, \& Basen-Engquist, K. (2004). Predictors of sexual functioning in ovarian cancer patients. Journal of Clinical Oncology, 22(5). 881-889.

Wabe, N. T., Angamo, M. T., \& Hussein, S. (2011). Medication adherence in diabetes Melitus and self management practices among type-2 diabetics in Ethiopia. North American Journal of Medical Sciences, 3, 418-423.

Weijmar, S.W., Basson, R., Binik, Y., Eschenbach, D., Wesselmann, U., \& Van Lankveld, J. (2005). Women's sexual pain and its management. Journal Sex Med, 2, 301-16.

World Health Organization. (2007). Definition, diagnosis and classification of diabetes melitus and its complications. Geneva.

World Health Organization (WHO). (2007). Reproductive health indicators for global monitoring. Report of an Inter-Agency Technical Group. WHO 9-11 April 2000. WHO Geneva.

Wyman, J.F., \& Fantl, J.A. (2001). Bladder training in ambulatory care management of urinary incontinence. Urologic Nursing, 13, $11-17$. 